\title{
Postnatal differentiation and endocrine control of esterase isoenzymes in the mouse epididymis
}

\author{
A. Abou-Haila and M. A. Fain-Maurel \\ Groupe d'Etude "Formation et Maturation du gamète mâle"*, Laboratoire de Biologie cellulaire, \\ U.E.R. Etudes Médicales et Biologiques, Université René Descartes, 45 rue des Saints-Pères, \\ 75270 Paris Cedex, 06, France
}

\begin{abstract}
Summary. At 2 weeks of age, 11 isoenzymes were expressed and similar banding patterns on vertical polyacrylamide gel electrophoresis (PAGE), stained by $\alpha$ - or $\beta$-naphthyl acetate as a substrate, were obtained for tissues or fluids from the proximal and the distal parts of the mouse epididymis. After this period, the emergence of new bands or the disappearance of certain others led to a regional differentiation which appeared progressively in tissues and fluids, earlier in the distal part than in the proximal part. The changes occurring during epididymal differentiation affected the isoenzymes specific to the epididymis more than those common to testis and serum.

Castration of adult mice induced a decrease in esterase activity and changes in the number of isoenzymes, leading to the loss of regional specificity of the banding patterns. The dedifferentiation process modified the electrophoretic profiles of the distal part only. Androgen replacement restored the regional specificity of cytosol banding patterns after 2 weeks of treatment and the normal intensity of bands after 4 weeks. Some differences in the fluid isoenzymes nevertheless persisted. The androgendependence of esterase isoenzymes can be attributed to circulatory hormones rather than to androgens from the testis via the rete testis as shown by efferent ductule ligation which did not modify the epididymal esterase profiles.
\end{abstract}

\section{Introduction}

Nonspecific esterases comprise a widely distributed complex group of enzymes (carboxylesterases, arylesterases, acetylesterases and cholinesterases) which exhibit a high degree of multiplicity (Masters \& Holmes, 1972; Deimling et al., 1985). In the mouse epididymis, carboxylesterases account for most of the total nonspecific esterase activity which exhibits marked differences in the electrophoretic banding patterns between the proximal and the distal parts of the duct. The epididymis is a complex organ which ensures a suitable environment for the maturation of spermatozoa in the proximal part (caput) and their survival in the distal part (corpus and cauda). The composition of the luminal medium is modified along the duct by the substances secreted or reabsorbed by the epithelial cells and those taken up by these cells from the bloodstream. The processes occurring in the epididymis are controlled by androgens which reach the epididymis by the bloodstream and also locally by the fluid entering from the testis (Bedford, 1975; Orgebin-Crist et al., 1975).

In pubertal mouse epididymides, a high level of esterase activity was detected histochemically in only one of the five segments of the head, segment IV. In the corpus and the cauda, enzyme activity was moderate (Fain-Maurel \& Abou-Haila, 1986). During postnatal differentiation of the

*Formation recommandée par la Direction de la Recherche. 
epididymis, the esterase activity present in the epithelium at birth persisted along the undifferentiated duct at the same intensity during the first 2 weeks, and then varied, producing the regional differentiation of the adult state (Abou-Haila \& Fain-Maurel, 1985). This suggests that these variations could be related to a differentiated pattern of gene action as has been shown in other organs (Deimling \& Böcking, 1976).

In the present investigation, postnatal differentiation and endocrine control of esterase isoenzymes, separated by PAGE, were studied in the proximal and distal parts of the mouse epididymis.

\section{Materials and Methods}

Male mice of the Swiss $\mathrm{OF}_{1}$ strain (Iffa Credo, France), maintained in our laboratory for a period of 3 years, were used. The prepubertal group was composed of 30 males killed at 2, 3 and 5 weeks of age. The adult population (50 mice) was divided into 4 groups at 3 months of age: (1) 16 intact mice; (2) 10 mice which had been bilaterally castrated 1 month earlier; (3) 16 mice prepared as in (2) but which had received ( 3 times/week) for 2 or 4 consecutive weeks an intraperitoneal injection of $0.56 \mathrm{mg}$ testosterone propionate in $0.2 \mathrm{ml}$ olive oil, and (4) 8 mice in which the efferent ductules had been bilaterally ligated 1 month earlier with respect to the vasculature of the epididymis.

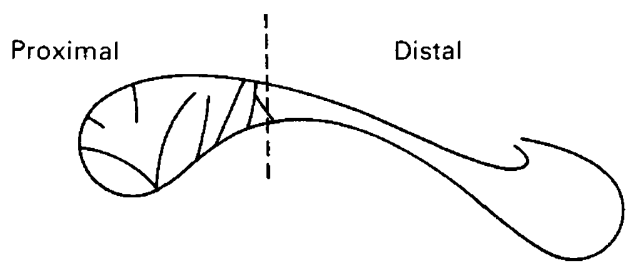

Fig. 1. Mouse epididymis. showing the subdivision into the proximal and the distal parts.

As previously described (Abou-Hatla \& Fain-Maurel, 1986), the mice were perfused through the left ventricle with $20 \mathrm{ml}$ saline $(9 \mathrm{~g} \mathrm{NaCl} / 1)$. The epididymides of 2 or 3 males of each group were combined and subdivided into 2 parts: the proximal part (caput) and the distal part (corpus and cauda) (Fig. 1). They were weighed, separately suspended in phosphate buffer saline (PBS) or Tris- $\mathrm{HCl}(0.02 \mathrm{M}, \mathrm{pH} 7.5)$ or distilled water $(100 \mathrm{mg}$ tissue $/ 100 \mu \mathrm{l})$, minced and shaken $\left(10 \mathrm{~min}, 20^{\circ} \mathrm{C}\right)$ to separate fluid from tissue. The tissue fragments washed and free of spermatozoa were homogenized in $0.2 \%$ aqueous Triton X-100 $(1: 2 \mathrm{w} / \mathrm{v})$. The fluid suspensions and the tissue homogenates were centrifuged $\left(27000 \mathrm{~g}, 30 \mathrm{~min}, 4^{\circ} \mathrm{C}\right)$ and the supernatants subjected to another centrifugation. Smears were obtained for the homogenates and the supernatants. Epididymal samples $(5-15 \mu \mathrm{l})$ were subjected to electrophoretic separation.

Vertical polyacrylamide gel electrophoresis (PAGE) was performed on $11 \%$ slab gels ( $\mathrm{pH} 8.2$ ) and was run on a Tris-glycine buffer system (pH 8.3) at a constant current of $120 \mathrm{~V}\left(10 \mathrm{~mA}\right.$ per gel plate) for $4-5 \mathrm{~h}$ at $4^{\circ} \mathrm{C}$.

The gels were stained $\left(1 \mathrm{~h}, 4^{\circ} \mathrm{C}\right)$ for esterase by coupling the reaction products of $\alpha$ - or $\beta$-naphthyl acetate $(0.04 \%)$ in $50 \mathrm{~mm}$-phosphate buffer ( $\mathrm{pH} 6.4)$ with fast blue B salt (0.07\%). Gel controls were incubated in a substrate-free medium.

The gels were scanned with an integrating densitometer (Cliniscan, Helena, France).

\section{Results}

Of the 16 esterase isoenzymes that have been previously identified in the epididymis of adult mice (Swiss $O F_{1}$ ), 8 are specific to the epididymis (see Table 1). The electrophoretic patterns differ between tissues and fluids as well as between the proximal and distal parts of the duct (Abou-Haila \& Fain-Maurel, 1986).

\section{Developmental events}

In the present study, 11 of the 16 epididymal isoenzymes were already expressed at 2 weeks of age. Similar banding patterns were obtained from the proximal and the distal parts for tissues and for fluids (Table 1; Fig. 2). 
Table 1. The presence $(+)$ or absence $(-)$ of esterase isoenzymes in epididymal tissue $(t)$ and fluid $(f)$ in the proximal (P) and distal (D) parts of the duct in mice at 2 weeks, 3 weeks and 3 months of age, in adult mice after castration, after hormone treatment of castrated animals, and after ligation of the efferent ductules

\begin{tabular}{|c|c|c|c|c|c|c|c|c|c|c|c|c|c|}
\hline & & & & iffe & atio & & & & & & & & \\
\hline & & & & & & & & Cas & on* & & & & \\
\hline & & $\mathrm{P}$ & $\mathrm{D}$ & $\mathbf{P}$ & D & $P$ & $\mathrm{D}$ & $P$ & D & $P$ & D & $P$ & $\mathrm{D}$ \\
\hline & $\mathrm{t}$ & + & + & + & + & + & + & + & + & + & + & + & + \\
\hline $\mathrm{E}_{1}$ & f & + & + & + & + & + & + & + & + & + & + & + & + \\
\hline$E_{2}$ & $\mathrm{t}$ & + & + & + & + & + & + & + & + & + & + & + & + \\
\hline $\mathrm{E}_{2}$ & f & + & + & + & + & + & + & + & + & + & + & + & + \\
\hline $\mathrm{E}_{1}$ & $t$ & - & - & - & - & - & - & - & - & - & - & - & - \\
\hline $\mathrm{L}_{3}$ & f & + & + & + & + & + & - & + & + & + & + & + & - \\
\hline$E_{4}$ & $\mathbf{t}$ & + & + & + & + & + & + & + & + & + & + & + & + \\
\hline $\mathrm{L}_{4}$ & f & + & + & + & + & + & + & + & + & + & + & + & + \\
\hline$E_{5}$ & $t$ & - & - & - & - & - & - & - & - & - & - & - & - \\
\hline & $\mathrm{f}$ & - & - & - & + & + & + & - & + & + & + & + & + \\
\hline$E_{G}$ & $t$ & - & - & - & - & + & - & - & - & + & - & + & - \\
\hline$L_{6}$ & f & - & - & - & - & + & + & - & - & + & + & + & + \\
\hline$E_{7}$ & $\mathrm{t}$ & + & + & + & + & + & + & + & + & + & + & + & + \\
\hline & $\mathrm{f}$ & + & + & + & + & + & + & + & + & + & + & + & + \\
\hline $\mathrm{E}_{\alpha}$ & $\mathrm{t}$ & - & - & + & + & + & + & + & + & + & + & + & + \\
\hline $\mathrm{E}_{8}$ & $\mathrm{f}$ & + & + & + & + & + & + & + & + & + & + & + & + \\
\hline $\mathrm{E}_{\mathrm{g}}$ & $\mathrm{t}$ & - & - & - & + & - & + & - & - & - & + & - & + \\
\hline & $\mathrm{f}$ & - & - & - & - & - & - & - & - & - & - & - & - \\
\hline$E_{10}$ & $\mathrm{t}$ & - & - & + & - & + & - & + & + & + & - & + & - \\
\hline$\sigma_{10}$ & f & + & + & + & + & + & - & + & + & + & + & + & - \\
\hline$E_{-}$ & $t$ & - & - & - & - & + & + & - & - & + & + & + & + \\
\hline $\mathrm{L}_{11}$ & f & - & - & - & + & + & + & - & - & + & + & + & + \\
\hline$E_{\text {, }}$ & $\mathrm{t}$ & + & + & + & + & + & + & + & + & + & + & + & + \\
\hline$L_{13}$ & $\mathrm{f}$ & + & + & + & + & + & + & + & + & + & + & + & + \\
\hline$E_{14}$ & $t$ & + & + & + & + & + & + & + & + & + & + & + & + \\
\hline 214 & $\mathrm{f}$ & + & + & + & + & + & + & + & + & + & + & + & + \\
\hline$E_{1}$ & $t$ & + & + & + & + & + & + & + & + & + & + & + & + \\
\hline & f & + & + & + & + & + & + & + & + & + & + & + & + \\
\hline$E_{17}$ & $t$ & - & - & - & - & - & - & - & - & - & - & - & - \\
\hline 17 & $\mathrm{f}$ & - & - & + & + & + & + & + & + & + & + & + & + \\
\hline$E_{18}$ & $\mathrm{t}$ & + & + & + & + & + & + & + & + & + & + & + & + \\
\hline $\mathrm{E}_{18}$ & f & + & + & + & + & + & + & + & + & + & + & + & + \\
\hline
\end{tabular}

Isoenzymes $E_{1}, E_{13}$ and $E_{14}$ are also found in testis; isoenzymes $E_{3}, E_{4}, E_{15}, E_{17}$ and $E_{18}$ are also found in testis and serum.

${ }^{*}$ Emergence of $\mathrm{E}_{\mathbf{6}}$ in tissue of the proximal part.

During epididymal differentiation, the emergence of some bands indicated that regional specificity appeared progressively in tissues and fluids. Several isoenzymes $\left(E_{8}, E_{9}, E_{10}\right.$ in tissue, $E_{17}$ in fluid) (Fig. 2) were expressed at 3 weeks, and one ( $E_{6}$ in tissue and fluid) later. The distal part of the epididymis reached its differentiation earlier (3rd week) than the proximal (5th week) part as shown by the expression of the isoenzymes $E_{5}$ and $E_{11}$ (Fig. 2). At 5 weeks, epididymal differentiation was complete for esterase isoenzymes. 


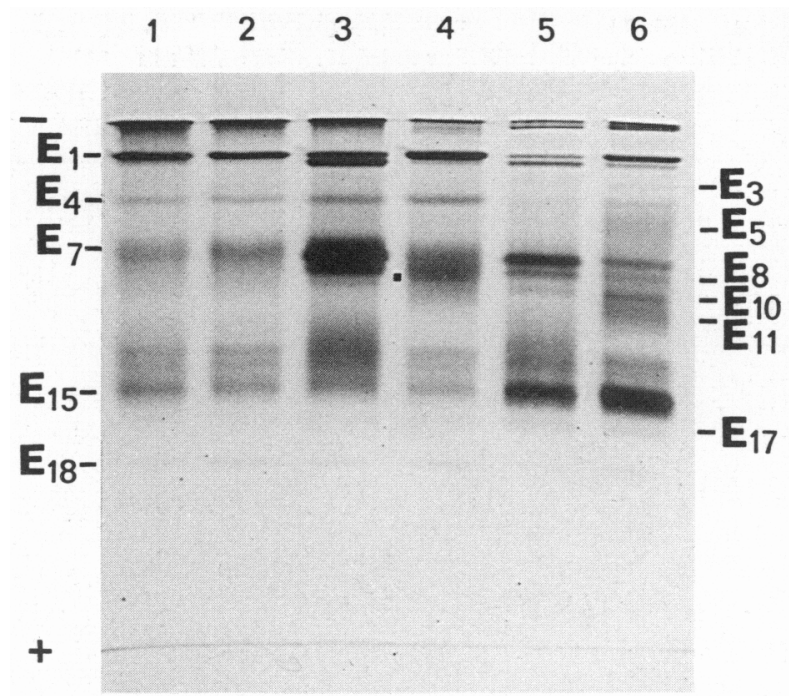

Fig. 2. PAGE at $11 \%$ ( $\alpha$-naphthyl acetate staining) at 2 (tracks 1,2$)$ or 3 (tracks $3,4,5,6)$ weeks of age on the tissues of the proximal (tracks 1,3) and distal (tracks, 2,4) parts and on the fluids of the proximal (track 5) and distal (track 6) parts of the epididymis. Note the identical pattern of the 2 parts of the epididymis at 2 weeks of age (tracks 1,2). At 3 weeks of age, new isoenzymes appear. $E_{5}$ and $E_{11}$ (track 6) and $E_{9}\left(G\right.$, track 4). $E_{8}$ and $E_{10}$ (tracks $\left.3,5,6\right)$ were already present in fluids at 2 weeks (not shown here).

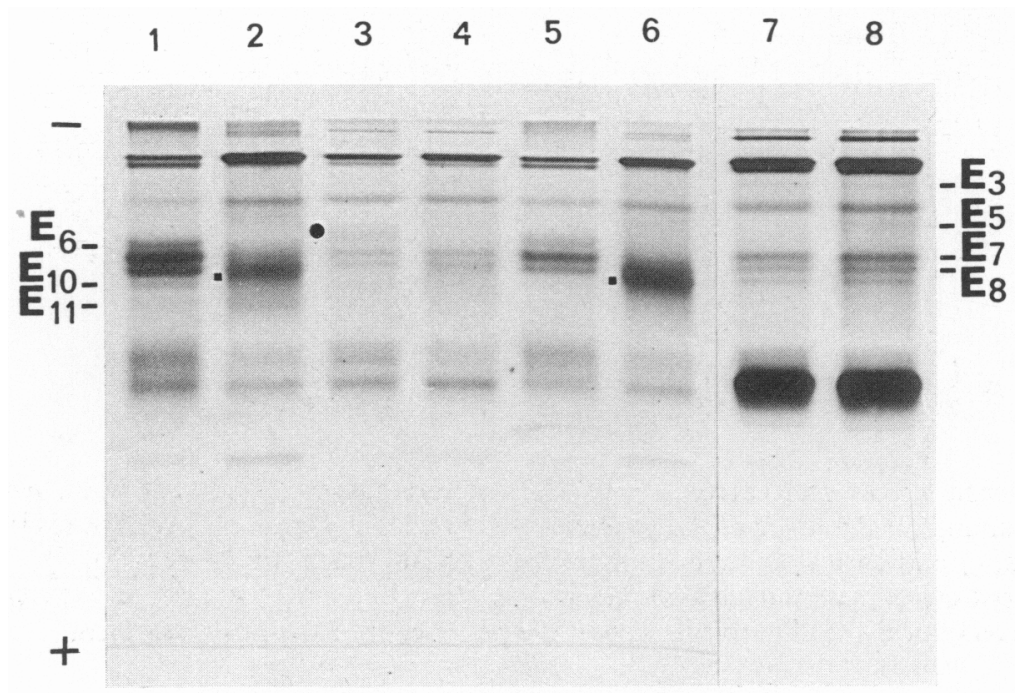

Fig. 3. PAGE at $11 \%$ ( $\alpha$-naphthyl acetate staining) of tissues in control (tracks 1,2$)$. castrated (tracks 3,4 ) and hormone-treated castrated (tracks 5, 6) adult mice of the proximal (tracks 1, 3, 5) and distal (tracks, 2, 4, 6) parts of the epididymis. Note the identical pattern in tissues of the two epididymal parts in castrated animals except for the emergence of an unusual band $E_{6 a}$ (O). Bands $\mathrm{E}_{6}, \mathrm{E}_{9}(\mathrm{G}), \mathrm{E}_{10}$ and $\mathrm{E}_{11}$ are absent. Androgen treatment restored the normal pattern. The weak bands $E_{10}$ and $E_{11}$ are not visible on this gel. The profiles of fluids in the proximal (track 7) and distal (track 8 ) parts of castrated animals are identical except for $E_{5}$ which showed a sharp decrease in intensity. 


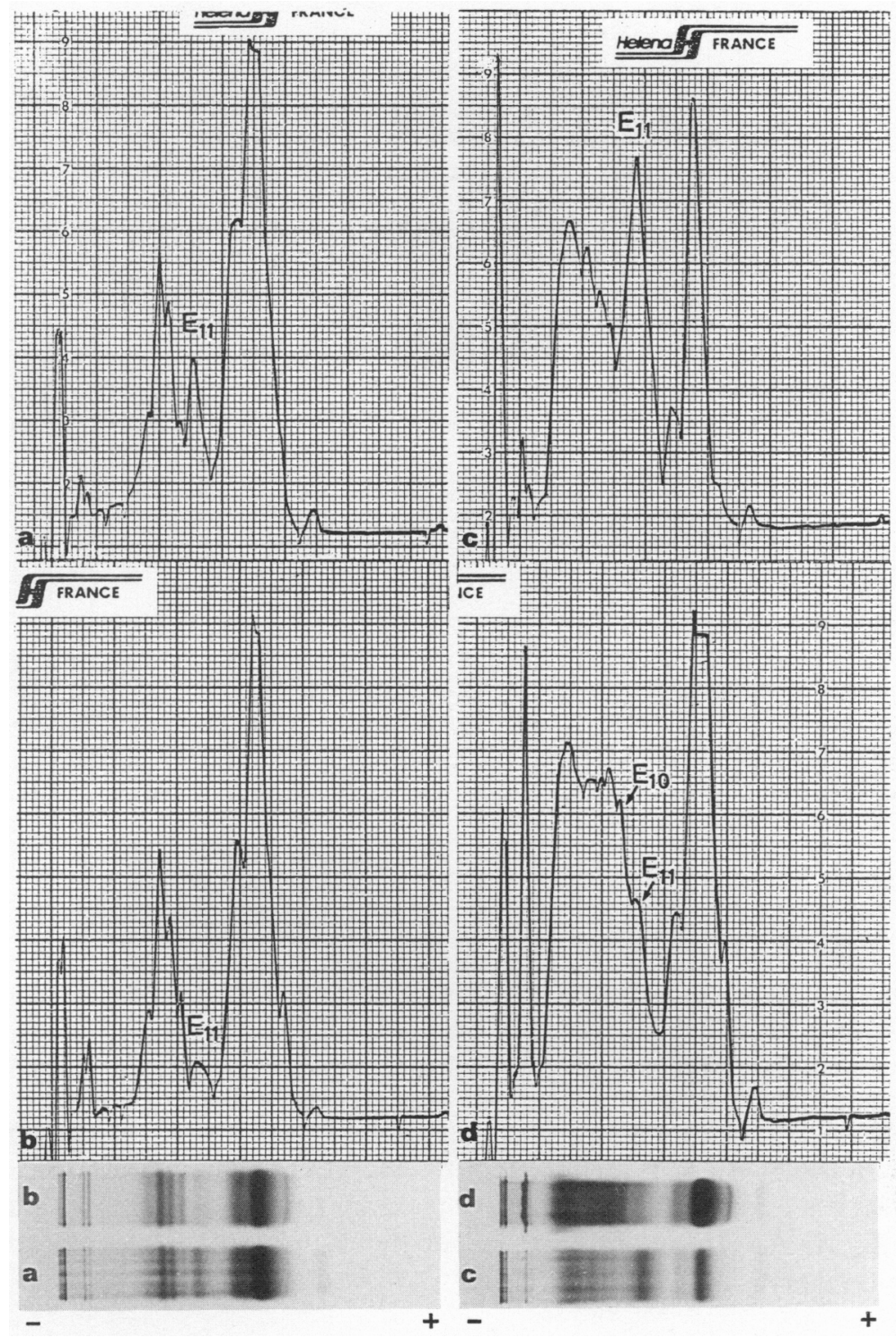

Fig. 4. Densitograms and corresponding electrophoretograms (PAGE at $11 \%, \alpha$-naphthyl acetate staining) of the fluids of the proximal $(a, b)$ and distal $(c, d)$ parts of the epididymis of normal $(a, c)$ and castrated adult mice treated with androgen for 4 weeks $(b, d)$. There are identical patterns between normal and hormone-treated animals for each part except for the lower intensity of $E_{11}$ and in the distal part the persistence of $E_{10}$ after treatment.

Among the 8 isoenzymes specific for the duct, $4\left(E_{5}, E_{6}, E_{9}, E_{11}\right)$ were still not expressed at 2 weeks, and $2\left(E_{8}, E_{10}\right)$ could only be detected at very low intensities in the fluids. For the isoenzymes common to the epididymis, testis, and serum, minor differences (absence of $\mathrm{E}_{17}$, presence of $E_{3}$ in the distal part) were observed.

Similar results were obtained when epididymal fragments were suspended in $\mathrm{PBS}$, Tris- $\mathrm{HCl}$ or distilled water. 


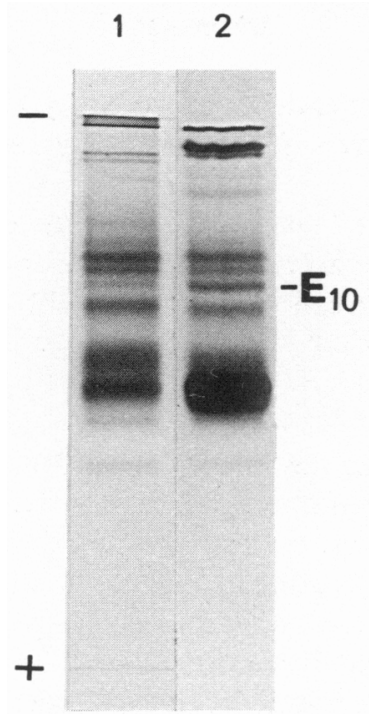

Fig. 5. PAGE at $11 \%$ ( $\alpha$-naphthyl acetate staining) of fluids of the proximal part of the epididymis in control (track 1) and efferent ductuli ligated (track 2) adult mice. Note the increase of band $\mathrm{E}_{10}$ after ligation.

\section{Effects of castration}

In castrated mice, there was a decrease in enzyme activity and the disappearance of isoenzymes $E_{6}$ and $E_{11}$ in the proximal and distal parts of the duct (Table 1; Fig. 3). The effects of hormonal deprivation on regional differences appeared selective (l) in tissues by the loss of $E_{10}$ specific to the proximal part, and $E_{9}$ specific to the distal part, and (2) in the fluid of the distal part, by the emergence of $E_{3}$ and $E_{10}$ which were specific to the proximal part. The electrophoretic patterns of tissues or fluids in the 2 parts have therefore mostly lost their regional specificity after castration. Only minor differences persisted between the two epididymal parts. These include the emergence of a new esterase $\left(E_{6 a}\right)$ in the tissue of the proximal part and the persistence of a low activity of $E_{5}$ in the fluid of the distal part.

\section{Effects of testosterone restoration}

In castrated animals treated for 2 weeks with testosterone propionate, the regional specificity of cytosol banding patterns reappeared, as did the luminal fluid of the proximal part. In the fluid of the distal part, isoenzyme activity was restored, but $E_{3}$ and $E_{10}$ were still present as in 3 week-old prepubertal mice. After 4 weeks of treatment, the intensity of all esterase bands was increased and similar to controls, except of $E_{11}$ which remained lower than in control mice (Table 1; Figs 3 \& 4).

\section{Effects of ligation of the efferent ductules}

Ligation of the efferent ductules for 4 weeks did not modify the epididymal banding patterns or the intensity of bands except for $E_{10}$ which increased in the fluid of the proximal part (Table 1; Fig. 5). 


\section{Discussion}

Esterase isoenzymes represent distinct entities controlled by 17 genes in the mouse (Peters, 1982) and thus appear to be useful markers for studying metabolic differentiation and hormonal modulation of the epididymis.

The present study revealed that, at 2 weeks of age, 11 esterase isoenzymes were expressed in the mouse epididymis and that the electrophoretic patterns of the proximal and distal parts were identical for tissues and fluids. This result can be correlated with the homogeneous esterase activity detected histochemically in the epithelium during this period (Abou-Haila \& Fain-Maurel, 1985). Cytological and histochemical data have shown that the development of regional differences occurs in the mouse epididymis between the 3rd and the 5th week (Abou-Hailla \& Fain-Maurel, 1985). Concerning the esterase activity during this time, the epididymal differentiation was marked by an increase or a decrease in the intensity of some esterase isoenzymes and the emergence of new ones. It can therefore be postulated that these esterases expressed later are related to a pattern of gene activation associated with cellular differentiation and/or the start of functional activity (Masters \& Holmes, 1975; Moss, 1979). Since the banding patterns of esterases becomes specific to the proximal and distal parts of the epididymis during its differentiation, it is likely that esterase metabolism is implicated structurally or functionally in the regional differences of the post-pubertal epididymis. The modifications linked to epididymal differentiation in the mouse can be correlated with a relatively high concentration of serum androgen (Okamoto et al., 1982), as shown in the genital tract of several species (Botte, 1980; Lancieri et al., 1980; Paino et al., 1981).

In the epididymides of castrated mice, the decrease of some isoenzyme activities and the disappearance of others were observed, as previously described for the whole mouse epididymis (Allen \& Hunter, 1960). The drop in esterase activity after castration reported here does not reflect a decrease of the epididymal weight induced by gonadectomy because the same dilution ( $\mathrm{w} / \mathrm{v}$ ) was used for the preparation of samples of non-castrated and castrated animals. It was also reported that the histochemical esterase reaction disappears or is greatly reduced in the epididymis of castrated mice of different inbred strains (Kirkeby \& Blecher, 1981). The emergence of a new isoenzyme $\left(\mathrm{E}_{6 \mathrm{a}}\right)$ in the cytosol of the proximal part after castration could reflect the de-repression of the corresponding gene by hormone deprivation. The same hypothesis could be put forward for isoenzyme $\mathrm{E}_{10}$ which was expressed in the distal part of the duct only after castration. The persistence of this esterase band after androgen treatment could involve the deprivation of another testicular factor or the physiological requirements of the adult epididymis since isoenzyme $\mathrm{E}_{10}$ was expressed in the distal part in 3-week-old prepubertal mice. In the present study, the identification of two androgen-dependent isoenzymes $\left(E_{5}, E_{11}\right)$ synthesized by the epididymis may provide insights into evaluation of this functionally multiglandular organ. However, the most striking finding was the observation of the same electrophoretic patterns in the proximal and distal parts of the castrated adult mouse epididymis (except for two minor bands, $E_{5}$ and $E_{6 a}$ ) as already seen in prepubertal 2-week-old animals (Fig. 6). It seems that some of the esterases are superfluous for the basic biochemical processes of cells lacking differentiation. Changes in esterase composition have also been seen after the loss of cellular differentiation in pathophysiological states (Kreusser, 1966; Kaneko et al., 1974). The loss of regional differences after castration only concerned the distal part where specific isoenzymes disappeared and characteristic isoenzymes of the proximal part appeared. It therefore seems that the esterase metabolism is less hormone-dependent in the proximal part than in the distal part. It has also been reported in the rat that, as regards their protein patterns, the caput epididymidis has a lower androgen requirement than does the cauda (Rajalaskshmi, 1985).

The administration of testosterone propionate to the castrated animals for 2 weeks was sufficient to restore the normal esterase cytosol patterns of the epididymis. The isoenzymes affected by castration can therefore be considered as androgen-dependent. For luminal fluids, an exception was observed for $E_{3}$ and $E_{10}$ expressed in the proximal part of the epididymis in the postpubertal 

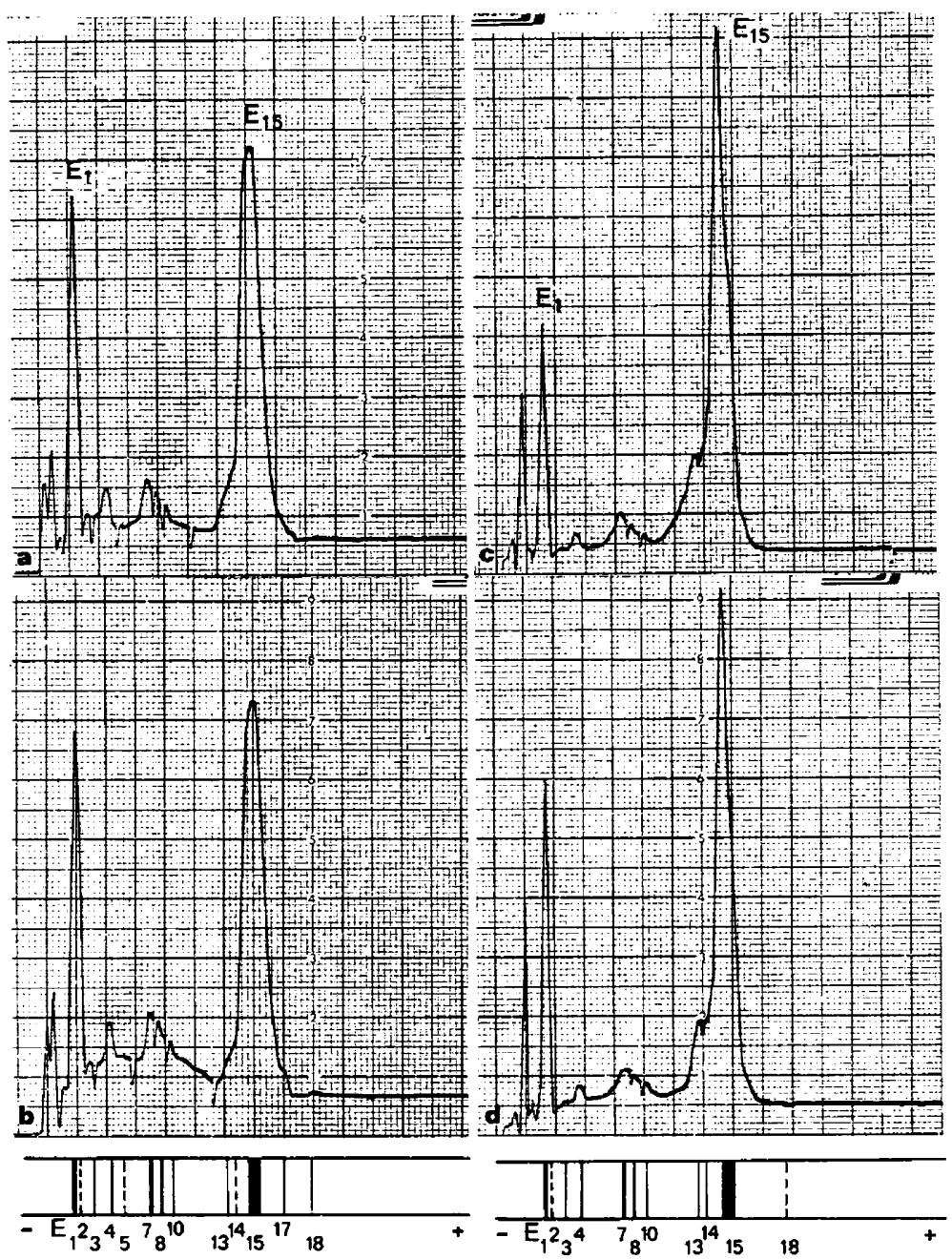

Fig. 6. Densitograms showing similarities between the fluids of castrated $(a, b)$ and 2-week-old (c, d) mice for the proximal (a, c) and distal (b, d) parts of the epididymis. The banding patterns of the distal parts corresponding to the electrophoretograms are represented below the graph. The very weak bands undetected by the Cliniscan are shown by broken lines.

mice. These isoenzymes, which appeared in the distal part of the epididymis only after castration, were not inhibited by the androgen replacement, sufficient for restoration of the other esterases. It is possible that the restoration of the normal behaviour of these isoenzymes requires a greater amount of testosterone, is dependent on another testicular factor or that these esterases are metabolized by spermatozoa stored in the distal part. This latter hypothesis might be supported by the detection of this enzyme in the distal part in prepubertal mice in which the epididymis is devoid of spermatozoa. The repression of the corresponding genes could be also dictated by the physiological requirements of the adult epididymis.

Ligation of the efferent ductules with respect to the epididymal vasculature produced a decrease in the total weight of the testis $(25 \%)$ and the epididymis $(25 \%)$, which appeared devoid of spermatozoa (unpublished observations). However, ligation did not modify the epididymal esterase banding patterns. This is not surprising because it has been shown that, after section of the 
efferent ducts, the mouse epididymides receive testosterone essentially via the blood supply, and that epididymal dihydrotestosterone, the main steroid in the caput and the corpus, is produced locally from circulating testosterone (Jean-Faucher et al., 1986). In the rat, the bilateral efferent duct ligation that also caused a significant drop in total testis weight, only induced a small decrease in the concentration of androgen in the blood (Jansz \& Pomerantz, 1986). Ligation of the efferent ductules only produced an increase of the intensity of one isoenzyme $\left(E_{10}\right)$ in the fluid of the proximal part. This might correspond to an increment of a secretory product release provoked by a cell injury, since atrophy of the initial segment has been observed in the mouse (unpublished observations), as in the rat (Fawcett \& Hoffer, 1979), after efferent duct ligation.

The androgen-dependence of nonspecific esterase isoenzymes therefore appeared to be dependent on circulating hormone rather than on androgens from the testicular fluid. The isoenzymes that are not affected by gonadectomy and hormone therapy may be involved in more basic activities such as tissue maintenance, and those isoenzymes that are affected by androgen treatment may have more specialized metabolic functions such as the regulation of water and electrolyte balance (Kimura et al., 1982) or the hydrolysis of short-chain esters of steroid hormones (Hattori et al., 1981). They could also interact with spermatozoa which acquire an esterase activity after their transit in the proximal part of the epididymis (Abou-Haila \& Fain-Maurel, 1983; Fain-Maurel \& Abou-Haîla, 1986).

We wish thank Mrs L. Klukvine for drawing the figures; Mrs M. Largeau for typing the manuscript; and C. Greenbaum for stylistic corrections.

\section{References}

Abou-Haila, A. \& Fain-Maurel, M.A. (1983) Enzyme activities in Cynomologus monkey and mouse spermatozoa evaluated histochemically during epididymal maturation. Archs Androl. 11, 101-113.

Abou-Haila, A. \& Fain-Maurel, M.A. (1985) Postnatal differentiation of the enzymatic activities in the mouse epididymis. Int. J. Androl. 8, 441-458.

Abou-Harla, A. \& Fain-Maurel, M.A. (1986) Electrophoretic characterization of mouse epididymal esterases in inbred lines and in a natural population. Andrologia 18 (in press).

Allen, J.M. \& Hunter, R.L. (1960) A histochemical study of enzymes in the epididymis of normal, castrated and hormone replaced castrated mice separated by zone electrophoresis in starch gels. J. Histochem. Cytochem. 8, 50-57.

Bedford, J.M. (1975) Maturation, transport and fate of spermatozoa in the epididymis. In Handbook of Physiology, Sect. 7: Endocrinology. Vol. V: Male Reproductive System, pp. 303-317. Eds D. W. Hamilton \& R. O. Greep. American Physiological Society, Washington, D.C.

Botte, V. (1980) Electrophoretic patterns of aspecific esterases and soluble proteins in the oviduct of the lizard, Podarcis s. sicula, during the annual cycle. Atti Accad. Naz. Lincei. Rend. Cl. Sci. Fis. Mat. Nat. 68, 86-90.

Deimling, O.V. \& Böcking, A. (1976) Esterases in histochemistry and ultrahistochemistry. Histochem. J. 8, $215-252$.

Deimling, O.V., Ronai, A. \& De Looze, S. (1985) Nonspecific esterases of mammalian testis. Comparative studies on the mouse (Mus musculus) and rat (Rattus norvegicus). Histochemistry 82, 547-557.
Fain-Maurel, M.A. \& Abou-Haila, A. (1986) Subcellular distribution of the nonspecific esterase in the mouse epididymis with special reference to regional differences. Anat. Rec. 214, 148-153.

Fawcett, D.W. \& Hoffer, A.P. (1979) Failure of exogenous androgen to prevent regression of the initial segment of the rat epididymis after efferent duct ligation or orchidectomy. Biol. Reprod. 20, 162-181.

Hattori, K., Kamio, M., Nakajima, E., Oshima, T., Satoh, T. \& Kitagawa, H. (1981) Characterization of steroid hormone ester hydrolyzing enzymes in liver microsomes. Biochem. Pharmacol. 30, 2051-2056.

Jansz, G.F. \& Pomerantz, D.K. (1986) A comparison of Leydig cell function after unilateral and bilateral cryptorchidism and efferent-duct-ligation. Biol. Reprod. 34, 316-321.

Jean-Faucher, Ch, Berger, M., Gallon, C., De Turchkheim, M., Veyssière, G. \& Jean, Cl. (1986) Regional differences in the testosterone to dihydrotestosterone ratio in the epididymis and vas deferens of adult mice. $J$. Reprod. Fert. 76, 537-543.

Kaneko, A., Dempo, K., Yoshiyasu, C.H. \& Onoé, T. (1974) Deviation in esterase isozyme pattern during early stage hepatocarcinogenesis by 3-methyl-4dimethylaminoazobenzene. Cancer Res. 34, 18161821 .

Kimura, K., Takagi, M., Igari, G., Ishii, M., Ikeda, T., Takeda, T. \& Murao, S. (1983) Histochemical localization of Kallikrein-like Pro-Phe-Arg-naphylester esterase activity in the rat kidney. Histochemistry $\mathbf{7 5}$, 91-98.

Kirkeby, S. \& Blecher, S.R. (1981) Histochemical studies on genetical control of hormonal enzyme inducibility 
in the mouse. IV: Cellular localization of androgen sensitive nonspecific esterase in the epididymis. Archs Androl. 6, 163-173.

Kreusser, E.H. (1966) Nonspecific esterases in normal and neoplastic tissues of the Syrian hamster: a zymogram study. Cancer Res. 26, 2181-2185.

Lancieri, M., Botte, V., Ferrara, A.M. \& Basile, C. (1980) Isoelectrofocusing of organic esterases in the postnatally developing and adult ovoviviparous teleost, Poecilia reticulata. Bas. appl. Histochem. 24, 23-31.

Masters, C.J. \& Holmes, R.S. (1972) Isoenzymes and ontogeny. Biol. Rev. 47, 309-361.

Masters, C.J. \& Holmes, R.S. (1975) Isoenzymes and phylogeny. In Haemoglobin, Isoenzymes and Tissue Differentiation, pp. 178-185. Eds A. Neureberg \& E. L. Tatum. North Holland Publ. Co., Amsterdam.

Moss, D.W. (1979) Isoenzyme analysis. Analyt. Sci. Monographs. 6, Chemical Soc. London, pp. 1-163.

Okamoto, S., Takatsuka, D., Tateishi, K., Ogasawara, Y., Yamane, T., Kitamura, Y. \& Matsumoto, K. (1982) Proliferative pattern of seminal vesicle cells and the production of testosterone and $5 \alpha$-androgens from birth to adulthood in mice. Endocrinology 111, 1230-1234.

Orgebin-Crist, M.C., Danzo, B.J. \& Davies, J. (1975) Endocrine control of the development and maintenance of sperm fertilizing ability in the epididymis. In Handbook of Physiology, Sect. 7: Endocrinology, Vol. V: Male Reproductive System, pp. 319-333. Eds D. W. Hamilton \& R. O. Greep. American Physiological Society, Washington, D.C.

Paino, G., Zigarelli, L., Pelagalli, G.V., Botte, V. \& Crasto, A. (1981) Electrofocusing of esterases and phosphatases of some sex accessory organs in male New Zealand rabbits during transpubertal maturation. Bas. appl. Histochem. 25, 199-211.

Peters, J. (1982) Nonspecific esterases of Mus musculus. Biochem. Genet. 20, 585-606.

Rajalakshmi, M. (1985) Hormonal regulation of specific proteins in the rat epididymis. Archs Androl. 14, 181-185.

Received 23 June 1986 